\title{
Chapter 13 \\ Protection and Consolidation of Stone Heritage by Bacterial Carbonatogenesis
}

\author{
Fadwa Jroundi, Maria Teresa Gonzalez-Muñoz, and \\ Carlos Rodriguez-Navarro
}

\begin{abstract}
For millennia, artists and architects around the world used natural stone for the carving of sculptures and the construction of monuments, such as Roman, Greek, and Maya temples, the European cathedrals, and the Taj Mahal, just to name a few. Currently, the survival of these irreplaceable cultural and historical assets is under threat due to their continued degradation caused by various biotic and abiotic weathering processes that affect not only the aesthetic appearance of these structures, but also their durability and survival. The natural precipitation of calcium carbonate minerals by bacteria has been proposed for conservative interventions in monument restoration. This chapter reviews the application of biomineralization by (indigenous) bacterial carbonatogenesis as a novel technology for the protection and consolidation of altered ornamental materials. Carbonatogenesis is based on the ability of some bacteria to induce calcium carbonate precipitation. Laboratory and in situ results support the efficacy of bacterial carbonatogenesis, since remarkable protection and consolidation are achieved on the surface and in depth, without alterations in color or porosity, and without fostering the development of microbiota that could be harmful to the stone material. A discussion on the advantages of this novel biotechnology is provided. Challenges and future work on bioconsolidation of stone artifacts are also outlined.
\end{abstract}

Keywords Consolidation · Stone $\cdot$ Biomineralization · Self-inoculation strategy · Indigenous bacteria $\cdot$ Cultural heritage $\cdot$ Conservation

F. Jroundi $\cdot$ M. T. Gonzalez-Muñoz

Department of Microbiology, Faculty of Science, University of Granada, Granada, Spain

e-mail: fadwa@ugr.es; mgonzale@ugr.es

C. Rodriguez-Navarro ( $\square)$

Department of Mineralogy and Petrology, Faculty of Science, University of Granada, Granada,

Spain

e-mail: carlosrn@ugr.es

(C) The Author(s) 2021

E. Joseph (ed.), Microorganisms in the Deterioration and Preservation of Cultural

Heritage, https://doi.org/10.1007/978-3-030-69411-1_13 


\section{Introduction}

The stone built heritage undergoes severe deterioration and damage resulting in the irreversible loss of priceless cultural assets (Crispim et al. 2003; Negi and Sarethy 2019). This alteration is a consequence of complex weathering phenomena in which physical, chemical, and biological processes are involved, which typically occur simultaneously, thus being difficult to distinguish the independent role played by each one (Strzelczyk 1981; Sebastián and Rodríguez-Navarro 1995; Saiz-Jimenez 1997; Warscheid and Braams 2000). Carbonate stones (limestone, marble, and dolostone) made up of calcium (and magnesium) carbonate minerals are since ages among the most commonly used in artworks and monuments. Despite their apparent strength, these materials are not highly durable; what is astonishing is that they are prone not only to chemical and physical damage but also to microbial attack. Carbonate stones are indeed highly susceptible to weathering factors, involving the interaction of several phenomena that include changing environmental conditions, such as temperature, relative humidity, $\mathrm{pH}$, and sun light, which altogether contribute to chemical, physical, and biological weathering processes (Warscheid and Braams 2000; Rodriguez-Navarro et al. 2011; Mihajlovski et al. 2017). One of the most remarkable phenomena in this regard is the effect of acid attack (for example, by the so-called acid rain) promoted by emissions of acid pollutant gases to the atmosphere from industries, heating and traffic (Rodriguez-Navarro and Sebastian 1996; Urosevic et al. 2012), and the formation of sulfate compounds (i.e., gypsum). But these phenomena of acid attack can also be a consequence of biodeterioration, being in many cases practically impossible to distinguish if the origin of the alteration is chemical or biological. In fact, the deterioration caused by biological agents (biodeterioration), which is conditioned by the development of living organisms, can cause weathering phenomena spanning from patina, which mask the surfaces, to severe damage derived from the production of very aggressive acids for the calcareous material such as sulfuric acid, produced by sulfur-oxidizing bacteria. The action of organic acids produced by a multitude of heterotrophic bacteria and fungi that are favored by organic pollutants is also deleterious for carbonate stones. For example, deterioration of marble at the cathedral of Milan has been associated with this type of organic acids (Strzelczyk 1981). All these types of alteration processes cause a gradual increasing of the material porosity, degrading its mechanical characteristics, causing the loss of cohesion and disintegration, and finally leading to their complete destruction. It is only in the last decades that this concern has received serious attention from scientists including archaeologists, geologists, chemists, biologists, and conservators aiming for the search of preventive and remedial strategies to preserve these historical monuments. This task is, however, challenging. Many attempts were directed towards the conservation and consolidation of such structures by using conventional methods including the use of inorganic and organic products that can act as protective coatings and/or consolidant agents (Lazzarini and Laurenzi Tabasso 2010; Rodriguez-Navarro et al. 2011). 


\section{Conventional Methodologies for Stone Conservation}

Organic products have been frequently used for their versatility, easy synthesis, and application methodology. This is the case of acrylic and epoxy resins or copolymers of a mix of diverse type of polymers. Among the non-polymeric products, there are organic ones such as oxalates which aim at mimicking the formation of natural protective patinas or inorganic ones such as calcium hydroxide solutions (lime water), which is a well-known treatment used since Roman times for in situ consolidation of objects made of calcium carbonate. Other family of products are alkoxysilanes such as ethyl silicate that generate a silica gel, frequently used for friable limestone and wall paintings consolidation, or alkyl alkoxysilanes which impart a dual protective and consolidation effect (Doehne and Price 2010). More recently, phosphates have emerged as protective coatings for carbonate stones (Sassoni et al. 2011). Some of these treatments have protective and sacrificial qualities, while others have more specific consolidating effects for limestone and lime plaster (Hansen et al. 2003). Although these traditional organic and inorganic consolidants resulted to be efficient in some cases, providing the stone with some hydrophobicity and/or consolidation effect, most of them, however, prove to have various disadvantages. They were prone to form superficial films that block the porous system or they caused alteration of the color and brightness of the treated stone, in addition to their limited resistance to alteration and their physico-chemical incompatibility with the original substrate. In some cases, very limited consolidation was achieved, as it is the case of the lime water technique which revealed ineffective, since precipitation of $\mathrm{CaCO}_{3}$ often led to the formation of a superficial, micrometerthick, friable aggregate of submicron-size calcite crystals, as a powder without cohesion that had an insufficient protection and/or consolidation effect (Price et al. 1988; Hansen et al. 2003; Doehne and Price 2010). These shortcomings have in part been overcome by the use of nanolimes, which are alcohol dispersions of $\mathrm{Ca}(\mathrm{OH})_{2}$ nanoparticles (Rodriguez-Navarro and Ruiz-Agudo 2018). In general, however, the use of conventional protection and consolidation treatments, sometimes indiscriminate, has led to the production of more drawbacks than those intended to be corrected (Rodriguez-Navarro and Ruiz-Agudo 2018). Additionally, large quantities of volatile organic solvents are commonly used during their application, which contribute to pollution (Rodriguez-Navarro et al. 2003; Doehne and Price 2010). Thus, most of the conventional treatments used so far in the conservation of decayed stone have revealed to be only partially successful for the preservation and consolidation of deteriorated monuments (Price et al. 1988; Hansen et al. 2003; Wheeler 2005; Rodriguez-Navarro et al. 2013). Moreover, some of them have been even harmful because they accelerated the deterioration of the treated stone (RodriguezNavarro et al. 2003; Doehne and Price 2010). To address the shortcomings of these conventional strategies, numerous efforts have been dedicated to the search and development of new more effective and compatible conservation treatments for the consolidation and protection of the stone cultural heritage. 


\section{New Methodologies for Stone Conservation}

In the last decades, bacterial biomineralization has been proposed as a compatible and an environmentally friendly technology for the protection of decayed ornamental stones, particularly those having a carbonate composition (such as limestone and marble) (Adolphe et al. 1990; Orial et al. 1993; Tiano et al. 1999; Castanier et al. 2000). This strategy takes advantage on the capacity of bacteria to induce the formation of calcium carbonate, which cements carbonate rocks and is a biogeochemical phenomenon that commonly occurs in a wide range of natural environments (Boquet et al. 1973). Although often bacteria have been related to harmful effects on stone structures, affecting the integrity of minerals or exacerbating powerful physico-chemical deterioration processes, there is increasing evidence that carbonate-producing bacteria (i.e., carbonatogenic bacteria) could be used to reverse or ameliorate the effects of weathering processes affecting stone objects of historical and artistic interest (Le Métayer-Levrel et al. 1999; Rodriguez-Navarro et al. 2003; Jimenez-Lopez et al. 2007, 2008; Dhami et al. 2014; Seifan and Berenjian 2019). The bacterial conservation method is based on the bacterially induced precipitation of a compatible calcium carbonate mineral cement on the stone substrate, and unlike most conventional treatments, the precipitate seems to be highly coherent (Le Métayer-Levrel et al. 1999; Rodriguez-Navarro et al. 2003).

Below, an attempt is made to provide an outline of the current methods based on bacterially induced carbonate mineralization for the conservation of stone works as a promising approach for the bioremediation of historical and important building materials.

\section{Bacterial Biomineralization of Calcium Carbonates}

Biomineralization refers to the process by which organisms synthesize minerals. It can be either biologically induced mineralization (BIM) or biologically controlled mineralization (BCM) (Lowenstan and Weiner 1989; Mann 1995; González-Muñoz et al. 2010). BCM commonly results in the formation of complex and specialized structures like skeletons, shells, and teeth, and occurs mainly in tissue-forming multicellular eukaryotes. These biogenic minerals are synthesized either intracellularly or extracellularly in a way that is unique to each species, independently of environmental conditions. The process is thought to be completely regulated under specific metabolic and genetic control (Bazylinski and Moskowitz 1997; Bäuerlein 2003; Baeuerlein 2004). Although rare, BCM also occurs in the case of microorganisms: well-known examples are magnetite mineralization by magnetotactic bacteria, as well as calcite precipitation and silica deposition by algae and diatoms, respectively (Bäuerlein 2003; Baeuerlein 2004; Bazylinski and Schübbe 2007). In contrast, in BIM, as it is the case of bacterial carbonatogenesis, the organisms do not control the biomineralization process directly. Due to their metabolism, they alter the 


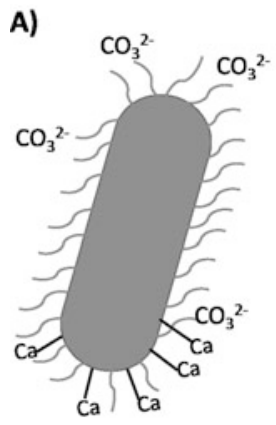

B)

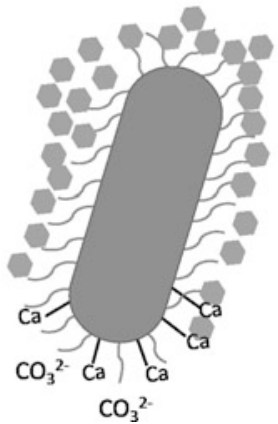

C)

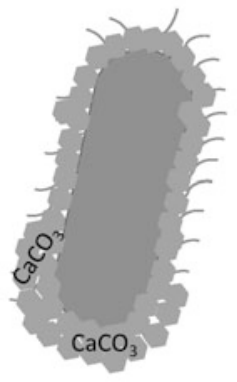

D)

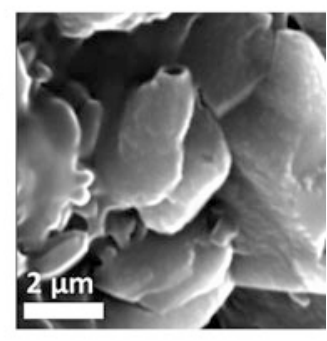

Fig. 13.1 Representation of the process of bacterially induced calcium carbonate precipitation. Calcium ions in the solution are attracted to the bacterial cell wall due to the negative charge of the latter. Oxidative deamination of amino acids results in the production of ammonia and $\mathrm{CO}_{2}$, which is converted into $\mathrm{HCO}_{3}{ }^{-}$or $\mathrm{CO}_{3}{ }^{2-}$ at higher $\mathrm{pH}$ in the microenvironment surrounding the bacteria (A). In the presence of calcium ions, this can result in the heterogeneous precipitation of calcium carbonate on the bacterial cell wall (B). The whole cell is finally entombed with time (C). Scanning electron Microscopy image (D) showing the imprint of a bacterial cell involved in calcium carbonate precipitation

geochemistry around their cells favoring mineralization. As a result, the type of mineral formed by BIM processes is strongly dependent on environmental conditions (Rivadeneyra et al. 1994; Ben Omar et al. 1997; Brennan et al. 2004). Different mechanisms/processes responsible for bacterial carbonatogenesis have been proposed, which result in extracellular mineral growth and contribute to the formation of calcium carbonate sediments and rocks (Chafetz et al. 1991; Folk 1993; Vasconcelos et al. 1995; Paerl et al. 2001; Zavarzin 2002; Sharma 2013). In addition to the bacterial metabolic pathways that shift the environmental $\mathrm{pH}$ to alkalinity and, in the presence of calcium ions, foster calcium carbonate precipitation, bacterial surfaces also play an important role in such a mineral formation by serving as heterogeneous nucleation sites (Fortin 1997; Rodriguez-Navarro et al. 2003). As a result of successive stratification of the carbonate precipitates on the bacterial external surface, bacterial cells can be embedded or entombed within the growing calcium carbonate crystals (Fig. 13.1).

BIM is the most commonly applied process in the field of stone protection and consolidation, an emerging interdisciplinary biotechnology that consists in the use of bacteria and their biological and metabolic pathways for the precipitation in the stone of different biominerals, depending on bacteria and substrate types (RodriguezNavarro et al. 2012). Nearly 64 varieties of minerals of phosphates, carbonates, silicates, iron and manganese oxides, sulfide minerals, and amorphous silica can be synthetized by different microorganisms using specific metabolic routes (Knoll 2003). Microbially induced carbonate mineral precipitation occurs via various heterotrophic pathways such as the nitrogen cycle, the sulfur cycle and iron reduction. In the nitrogen metabolism, calcium carbonate precipitation is thought to 


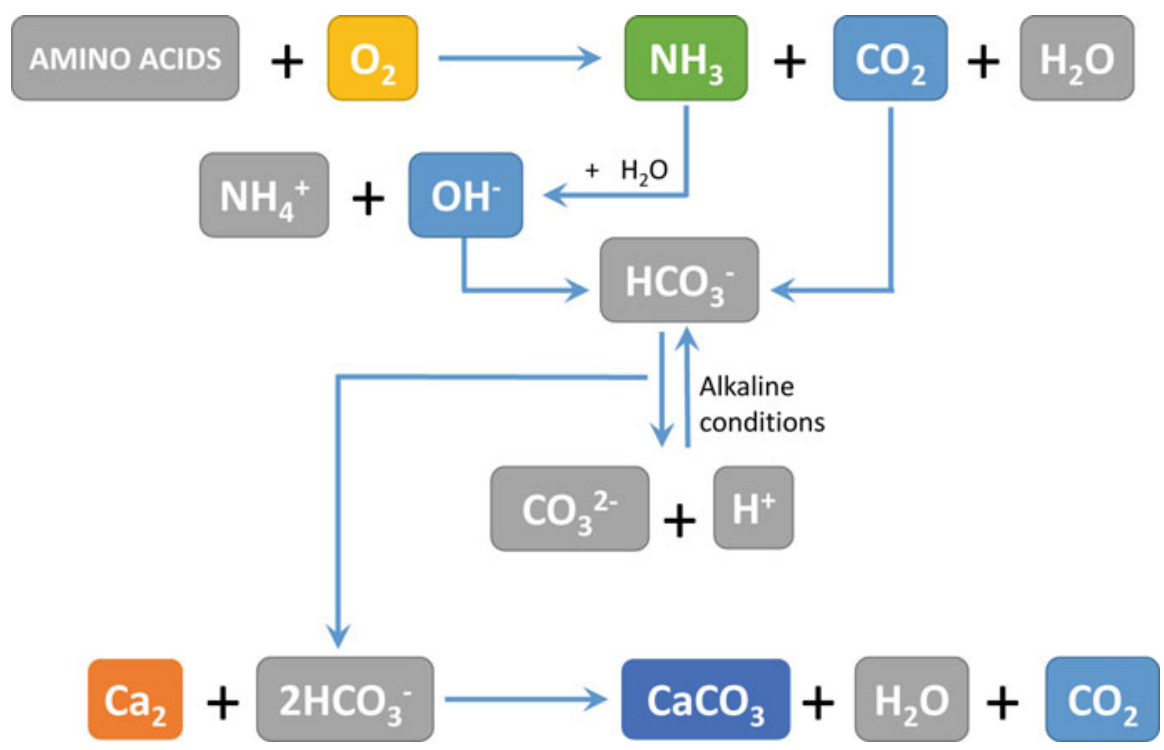

Fig. 13.2 Bacterially induced mineralization occurring by oxidative deamination of amino acids via complex biochemical reactions

operate in the presence of oxygen (aerobiosis) by two different metabolic pathways, including amino acid and peptide catabolism (e.g.,: Rodriguez-Navarro et al. 2003, 2007; González-Muñoz et al. 2010; Jroundi et al. 2012), or degradation of urea or uric acid (Le Métayer-Levrel et al. 1999; Okwadha and Li 2010; De Muynck et al. 2010, 2013; Heidari Nonakaran et al. 2015; De Belie et al. 2018); both of which are important in increasing the local $\mathrm{pH}$ and inducing the production of carbonate ions.

Through the degradation of urea, ureolytic bacteria increase the concentration of dissolved inorganic carbon (DIC) and $\mathrm{pH}$. During this process, carbamate is first produced by urease-catalyzed urea hydrolysis (Eq. 13.1). This carbamate intermediate spontaneously hydrolyzes to ammonia and carbonic acid (Eq. 13.2). Afterwards, these products equilibrate in the presence of water, forming bicarbonate, carbonate, and ammonium ions, as well as hydroxyl ions, thereby increasing the $\mathrm{pH}$ (Eqs. 13.3, 13.4). Finally, in the presence of calcium, these reactions induce the precipitation of calcium carbonate (Eq. 13.5) in an alkaline environment (De Muynck et al. 2010).

Urease

$$
\begin{gathered}
\mathrm{CO}\left(\mathrm{NH}_{2}\right)_{2}+\mathrm{H}_{2} \mathrm{O} \rightarrow \mathrm{NH}_{2} \mathrm{COOH}+\mathrm{NH}_{3} \\
\mathrm{NH}_{2} \mathrm{COOH}+\mathrm{H}_{2} \mathrm{O} \rightarrow \mathrm{NH}_{3}+\mathrm{H}_{2} \mathrm{CO}_{3} \\
\mathrm{H}_{2} \mathrm{CO}_{3} \rightarrow 2 \mathrm{H}^{+}+\mathrm{CO}_{3}^{2-} \\
\mathrm{NH}_{3}+\mathrm{H}_{2} \mathrm{O} \rightarrow \mathrm{NH}_{4}^{+}+\mathrm{OH}^{-} \\
\mathrm{Ca}^{2+}+\mathrm{CO}_{3}^{2-} \rightarrow \mathrm{CaCO}_{3}
\end{gathered}
$$


Some Gram-negative aerobic microbial strains are able to use amino acids as their sole source of energy to initiate the biomineralization of calcium carbonate through amino acid and peptide catabolism in aerobiosis (Fig. 13.2). As shown in Fig. 13.2, carbon dioxide and ammonia are produced by oxidative deamination of amino acids. Ammonia (Eq. 13.4) increases the alkalinity in the microenvironment around the cell, whereas $\mathrm{CO}_{2}$ dissolves and transforms into either $\mathrm{HCO}_{3}{ }^{-}$or $\mathrm{CO}_{3}{ }^{2-}$ at higher $\mathrm{pH}$. Here also, the presence of calcium and an alkaline environment favors the precipitation of calcium carbonate by heterogeneous nucleation on the bacterial cell walls and cell debris (Rodriguez-Navarro et al. 2003), and on the extracellular polymeric substances (EPS) forming a biofilm (Jroundi et al. 2017).

Incorporation of organics (bacterial cells or EPS) into the bacterial calcium carbonate crystals (vaterite and calcite) has been shown (Rodriguez-Navarro et al. 2007; Jroundi et al. 2017). EPS produced by bacteria have been demonstrated to be involved in biocalcification by entrapping calcium and carbonate ions and serving as a nucleation site (Braissant et al. 2003; Zamarreño et al. 2009). In Pseudomonas fluorescens, morphology and mineralogy of the carbonate crystals formed was demonstrated to be influenced by the composition and concentration of EPS (Braissant et al. 2003). Also, EPS appears to be involved in the aggregation of smaller crystals resulting in the growth of the final larger crystals (Buczynski and Chafetz 1991). This process is commonly extracellular, occurring in the area surrounding the cells, and often leading to the join mineralization of EPS and bacterial cells (Fig. 13.1D) that become the nucleus of the biominerals (Ehrlich 1998; Rodriguez-Navarro et al. 2007).

The pathways of calcium carbonate formation described above are ubiquitous in nature, accounting for the common occurrence of microbial carbonate precipitation (MCP) and confirms what Boquet et al. (1973) earlier reported, i.e., that most soil bacteria are able to induce the precipitation of carbonates under suitable conditions. This ability that bacteria have to promote carbonate mineral formation allowed the search and proposition, back in the 1990s, of a new kind of stone conservation treatment based on bacterial biomineralization. In the last few decades, the potential of bacterial biomineralization processes and their application to the conservation and consolidation of cultural heritage have drawn a widespread interest and since a while this is a matter of considerable attention and investment (e.g.,: Adolphe et al. 1990; Orial et al. 1993; Castanier et al. 2000; Rodriguez-Navarro et al. 2003; DaSilva 2004).

\section{International Research Groups Involved in Bacterial Biomineralization}

The biomineralization strategy for stone protection have had several propositions. Among the firsts to consider the use of bacterially induced calcium carbonate precipitation to stone conservation and protection were Adolphe et al. (1990) 
through the CALCITE Bioconcept, a patented technique developed at the Universite Pierre et Marie Curie in Paris, which involved the application to the stone of carbonatogenic bacteria. These authors demonstrated the ability of carbonatogenic bacteria, typically those inhabiting soils (Boquet et al. 1973), to precipitate calcite on damaged limestone surfaces, thus inducing their protection and consolidation. Further research was performed by Orial et al. (1993) from the University of Paris VI who explored the application of living cultures of selected carbonatogenic bacterial strains for calcite formation on stone and the replacement of the natural reinforced layer (CALCIN).

The technique was further optimized and industrialized by a collaboration between the French Company CALCITE, the University of Nantes, and the Historical Monuments Research Laboratory (LRMH). They carried out in situ tests and the application to historic monuments observing the reinforcement and consolidation of weathered stone. The first in situ application was carried out in 1993 in Thouars on the tower of the Saint Médard Church (Le Métayer-Levrel et al. 1999). The researchers also described the "successful" application of the CALCITE method on a sixteenth century limestone castle. Afterwards, a number of buildings in France were treated using this technique, including a castle at Châteaudun (Eure-et-Loir) and the Bordeaux cathedral (Castanier et al. 2000). There, it was reported the successful precipitation of the biocalcin layer, which resulted in no side effects on the esthetic appearance and highly reduced water absorption rate. Nevertheless, Orial (2000) concluded that every 10 years a new treatment would be needed to restore the protective effect of the biocalcin. In addition, upon investigating different bacteria, the authors selected Bacillus cereus cultures for in situ applications, which may pose different health risks (Perito et al. 1999). Furthermore, since only a few micrometers thick consolidated layer was observed, the ineffectiveness for in-depth consolidation was another main drawback of this technique (Le Métayer-Levrel et al. 1999; Rodriguez-Navarro et al. 2011).

Tiano (1995) proposed another approach for the conservation of calcareous stone based on the use of the "organic matrix" macromolecules extracted from shells of Mytilus californianus (a mollusc), which were applied on a sample of limestone to induce the mineralization process. With this technique, a good efficiency of the calcium carbonate precipitation process was showed leading to an increase in the strength of the surface of treated stone and a decrease in the water absorption rate. However, in situ tests were not successful and the application of organic matter posed a risk as it could promote the development of harmful heterotrophic microorganisms. This was one of the two research lines attempted by the European project BIOREINFORCE (BIOmediated calcite precipitation for monumental stones REINFORCEment, 2001-2004), which aimed at utilizing molecular biology and bacterial genetic engineering to elucidate the genetic background of crystal formation as an innovative alternative to the production of biomineralization-inducing macromolecules for the improvement of the biomediated calcite precipitation. At first, the consortium looked for molecules or structures from bacterial origin able to induce calcium carbonate precipitation. They demonstrated the ability of dead cells and cell fragments (BCF) from active carbonatogenic strains (Bacillus cereus and Bacillus 
subtilis) to induce higher and/or faster production of calcium carbonate crystals with a more complex shape than those produced by dead cells from less active strains (Escherichia coli). BCF application to stone resulted in a slight decrease in water absorption, with better effects on highly porous stones. Here again, this method revealed to be more useful for delicate small calcareous stone pieces than for entire buildings (Mastromei et al. 2008). The second research line consisted in identifying genes involved in the bacterial carbonatogenesis and the production at large-scale of macromolecules in bacterial cultures (Barabesi et al. 2007). The authors showed the presence in Bacillus subtilis of lcfA and etfA as operon and gene, respectively, which were involved in calcite precipitation and suggested a possible link between this precipitation and the fatty-acid metabolism (Barabesi et al. 2007; Perito and Mastromei 2011).

Tiano et al. (1999) evaluated the ability of Micrococcus sp. and B. subtilis in the consolidation and protection of a highly porous limestone (Pietra de Lecce). They reported the physical obstruction of the stone pores by the presence of a consistent layer of biological material (biofilm formation) and pointed out other potential drawbacks such as the reaction of stone and bacterial activity by-products or the modification of stone color.

Dick et al. (2006) proposed the application of several Bacillus species in a treatment that proceeded sequentially and in alternative cycles to biofilm formation and $\mathrm{CaCO}_{3}$ precipitation on Euville limestone (from quarries of the "Département de la Meuse" in France). The aim of their study was to determine the microbial key factors contributing to the performance of such treatment. Overall, several parameters were examined such as deposition of dense crystal layers, urea degrading capacity, $\mathrm{pH}$ increase, calcite deposition on limestone, EPS-production, biofilm formation, the $\zeta$-potential. According to the authors, optimal deposition of a $\mathrm{CaCO}_{3}$ layer in the treated limestone was based on a decrease in the water absorption rate. They finally concluded that the dense calcium carbonate crystals formed by Lysinibacillus sphaericus (=Bacillus sphaericus) were most suitable for coherent calcite production on degraded limestone and should be regarded as coating systems (Dick et al. 2006). Subsequently, the same bacterium was used for the bacterial deposition of a layer of calcite on the surface of concrete and mortars, which resulted in an improvement of the mortar resistance and the concrete durability with a more remarkable decrease in water uptake and a limited change of the chromatic aspect as compared to a treatment based on mixed ureolytic cultures (De Muynck et al. 2008a, b).

The BIOBRUSH (BIOremediation for Building Restoration of the Urban Stone Heritage) EU project was aimed at sequentially integrating salt removal and stone consolidation (May 2005). Within this project, Cappitelli et al. (2007) proposed a Carbogel as a delivery system for highly carbonatogenic bacteria such as Desulfovibrio vulgaris, which in addition to the elimination of black crusts also resulted in the conversion of gypsum to calcite. According to these authors, this delivery system could be employed for the control of potential harmful side effects of bacteria (Cappitelli et al. 2007). However, the practical applicability of such methodology was challenged by the complexity of the procedure and the necessity 
of a 2-weeks treatment for the confirmation of its effectiveness as consolidant. Furthermore, no information was provided neither on how the new calcite crystals were attached to the stone surface nor on the degree of stone reinforcement.

Daskalakis et al. (2013) proposed the use of Pseudomonas, Pantoea and Cupriavidus strains as candidate for bioconsolidation and protection of ornamental stones. They consolidated marble specimens and demonstrated a weight increase, due to the partial or even complete covering of the marble surfaces with (mainly) vaterite. Calcium carbonate precipitation induced by bacteria using only Cupriavidus metallidurans was then investigated to elaborate an environmentally friendly technique for the preservation and restoration of ornamental stones (Daskalakis et al. 2014). Further, these authors investigated the capacity of Bacillus pumilus for biomineralization on marble and reported that the rate of stone loss was reduced by the fine layer of bacterial calcium carbonate precipitated and B. pumilus proved to be useful as a candidate for in situ applications for stone conservation (Daskalakis et al. 2015).

Rodriguez-Navarro et al. (2003) proposed the use of Myxococcus xanthus, a non-pathogenic Gram-negative soil bacterium, and a nutritional solution that induced the precipitation of calcium carbonate within decayed stones. Depending on the culture media in which it grows, M. xanthus can induce the formation of a wide variety of biominerals, including phosphates (struvite: Gonzalez-Muñoz et al. 1993; Ben Omar et al. 1994, 1995, 1998), carbonates (calcite, Mg-calcite, vaterite: González-Muñoz et al. 2000; Rodriguez-Navarro et al. 2003; Chekroun et al. 2004; Rodriguez-Navarro et al. 2007) and sulfates (barita, taylorita: González-Muñoz et al. 2003). According to Rodriguez-Navarro et al. (2003), the treatment resulted in a deeper consolidation of calcarenite with a newly formed calcium carbonate cement in comparison to other known strategies for $\mathrm{CaCO}_{3}$ precipitation in stone. Calcium carbonate precipitation typically occurred on the bacterial cell walls, where heterogenous nucleation was facilitated, and the calcite crystals grew as a coherent cement (often epitaxially) on the stone support without plugging or blocking the porous system. In this case, bacterial calcium carbonate cement was observed up to a depth of several hundred micrometers $(>500 \mu \mathrm{m})$. These authors also showed that the newly produced bacterial cement was tougher and more resistant to dissolution than the original calcite in the stone, resulting from the incorporation of organic by-products of bacterial activity into the precipitated bacterial calcite. Interestingly, Chekroun et al. (2004) and Rodriguez-Navarro et al. (2007) showed that polymorph selection in carbonate precipitation was not strain specific, since in the case of bacteria such M. xanthus vaterite and calcite (or other minerals) can be precipitated just by modifying the composition of the culture medium (Fig. 13.3). These results suggested that an accurate selection of the growth media and the bacterial strains could yield to improved protection and consolidation of ornamental stones with different composition and textures. Similar results were also reported on non-porous marble, demonstrating that bacterial carbonatogenesis was not only effective in preserving porous stones but also in conserving non-porous ones (RodriguezNavarro et al. 2011). 

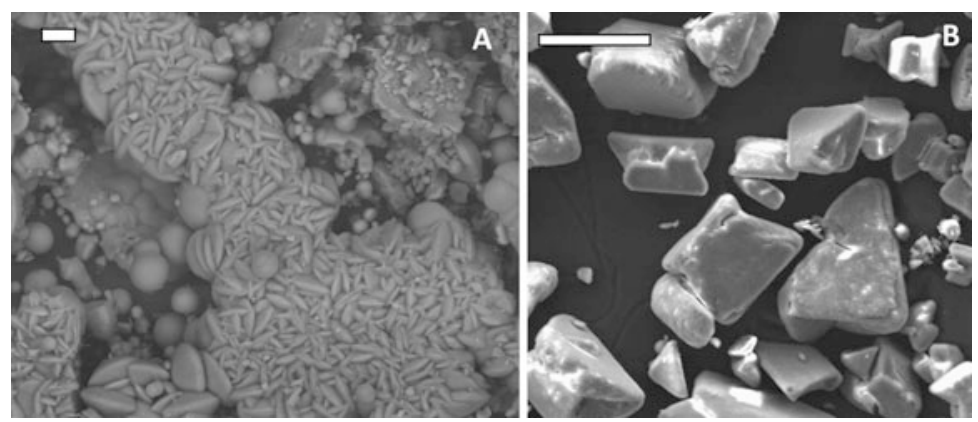

Fig. 13.3 SEM photomicrographs of different crystals induced by M. xanthus. (A) Vaterite crystals in M-3P culture medium. (B) Struvite crystals in CT medium (Ben Omar et al. 1998). Bar represent 10 and $100 \mu \mathrm{m}$ in $\mathrm{A}$ and $\mathrm{B}$, respectively

One of the most interesting aspects of this research has arisen when trying to apply this treatment on altered ornamental rocks, simulating real conditions of application in historic buildings (Jimenez-Lopez et al. 2007, 2008). In this case, it was observed that the degree of production of bacterial carbonate cement, and therefore the degree of consolidation achieved, was substantially higher than after the treatment of sterilized rocks. Such data pointed to the existence of a synergistic action between the bacteria existing in the altered stone and the biomineralization treatment with M. xanthus (Jimenez-Lopez et al. 2007). Nevertheless, exogenous bacteria or stone-isolated single bacterial cultures are likely at a competitive disadvantage with respect to the bacteria already present and/or better adapted to the local microenvironment in the stone. Furthermore, the application of an exogenous culture or a stone-isolated single bacterium may unpredictably alter the dynamics of the bacterial community in the stone, which is an important limitation of this strategy.

\section{The University of Granada Stone Consolidation Patent}

Subsequently, successful consolidation effects were achieved by the application of a sterile nutritional solution that activates the indigenous microbiota present on the stone and promotes the selective growth of carbonatogenic bacteria, as demonstrated by Gonzalez-Muñoz et al. (2008). This finding led to the development of a nutritional solution (M-3P) and a bacterial consolidation method patented in 2008. Here again, as with the first strategy, this new one, i.e., the application of sterile nutritional solution to the stone, resulted in the formation of calcium carbonate cement that protected and consolidated weathered stones.

This patented strategy was tested in different situations. In situ treatments were carried out in three historical monuments (Monastery of San Jeronimo, Royal Hospital, and Royal Chapel) placed in an urban environment in Granada, taking into account different locations, orientations, and degree of stone deterioration, so 
that more extensive information could be provided on the suitability of the patented methodology (Jroundi et al. 2010; Ettenauer et al. 2011; Rodriguez-Navarro et al. 2015). The results showed that in the first two historical buildings, a very similar degree of consolidation was achieved regardless of the type of treatment performed (with or without the additional foreign bacteria $M$. xanthus). Besides, the strengthening associated with the production of the newly formed calcium carbonate cement at both buildings allowed reinforcing the porous system and binding the loose grains of the stone with such a bacterial cement, which lasted (at least) for up to 4 years after application (Jroundi et al. 2010; Rodriguez-Navarro et al. 2015). Regarding the Royal Chapel, the in situ treatment was simultaneously performed during the application of ethyl silicate as a conventional treatment, to compare the degree of consolidation obtained by both types of treatments, in combination with a biocide application as a cleansing pre-treatment performed four-month prior to the consolidation treatments. The stone strengthening in this case was due to the new formation of bacterial calcite crystals without plugging the pores, thereby proving that the bacterial consolidation using a sterile nutrititional solution was as efficient as the traditional ethyl silicate consolidant (Jroundi et al. 2013). In addition, the evolution of the microbiota in all three historical buildings was assessed by culture-dependent and independent techniques and the results revealed that the majority of carbonatogenic bacteria were activated by the application of the patented M-3P nutritional solution and no negative effects associated with the possible activation of deleterious microbiota were observed (Ettenauer et al. 2011; Jroundi et al. 2010, 2015; Rodriguez-Navarro et al. 2015). Overall, the results of these studies showed that the in situ application of the bacterial consolidation method demonstrated no detrimental side effects on the stones with a highly proved medium- and long-term effectiveness.

\section{Self-Inoculation with Indigenous Carbonatogenic Bacterial Community}

When applied to heavily salt weathered stones, both previously described strategies (with or without additional bacterium) demonstrated to have a limited efficacy. Their effectiveness depended also on the stone characteristics (e.g., porosity, mineralogy, level of deterioration), the type of exogenous microorganism and bacterial load applied, and its interaction with indigenous microbiota. Salt weathering is known to be highly deleterious (Rodriguez-Navarro and Doehne 1999; Schiro et al. 2012; Flatt et al. 2014) and usually results in the partial filling of stone pores with soluble salts (Webster and May 2006), which may further inhibit the proliferation of indigenous or exogenous carbonatogenic bacteria. Therefore, a novel environmentally friendly bacterial self-inoculation approach was recently proposed to overcome the limitations associated to the existing two bacterial biomineralization strategies (i.e., (i) inoculation with a single carbonatogenic bacterial strain, and (ii) activation 


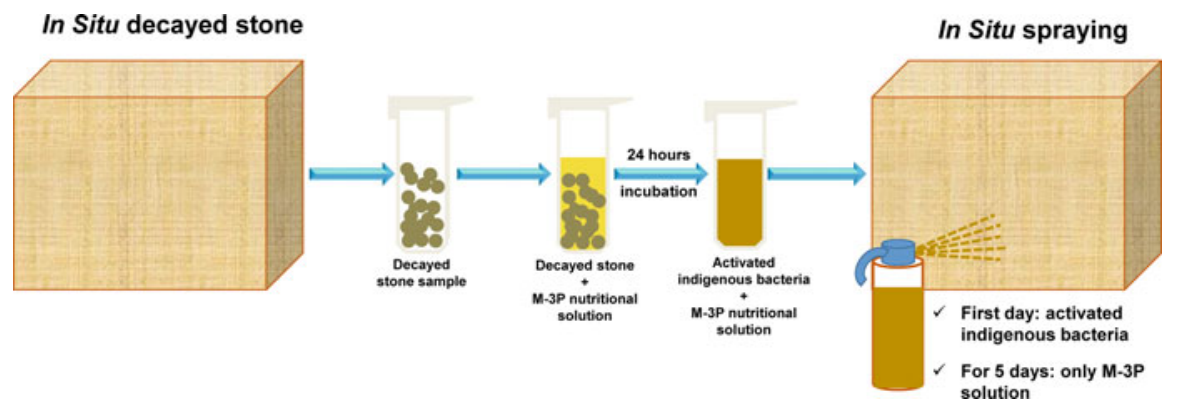

Fig. 13.4 Workflow for the application of the environmentally friendly bacterial self-inoculation conservation treatment

of the indigenous carbonatogenic microbiota with a sterile nutrititional solution) currently applied in the field of stone conservation. This novel technique was based on the isolation from heavily salt damaged stone of an indigenous community of carbonatogenic bacteria followed by their activation by culturing (in the laboratory) and re-application back onto the same stone (Fig. 13.4). This methodology was in situ tested in a historic building (San Jeronimo Monastery) in Granada, Spain, where the indigenous bacterial community was collected from carbonate stone that had suffered considerable damage due to salt weathering. In the laboratory, the bacterial community was identified following activation with the patented M-3P nutritional solution and the whole carbonatogenic bacterial community was subsequently applied in situ, i.e., self-inoculation, along with M-3P, to the same stone from which it was isolated. The protection and consolidation effectiveness of this novel conservation method was evaluated and proved both in situ and in the laboratory. Results showed that this third bacterial conservation method provided a greater protection and consolidation to the salt weathered stones than the two previous methods above described. In this case, the effective stone protection and consolidation resulted from the formation of an abundant and exceptionally strong organicinorganic hybrid cement consisting of a combination of nanostructured bacterial $\mathrm{CaCO}_{3}$, bacterially-derived organics, and calcified bacterial EPS, all of which covered the calcitic substratum protecting the stone from chemical weathering (i.e., dissolution) (Jroundi et al. 2017).

The proposed self-inoculation approach for the conservation of stone has proven to have superior advantages over other techniques as it facilitates the formation of calcium carbonate cement by the activated indigenous bacteria and offers protection to the stone which guarantees the activity of the stone indigenous carbonatogenic community and the further consolidation of the heavily salt weathered stone. Remarkably, such a treatment helps to reduce the amount of deleterious microorganisms involved in biodeterioration, likely because they are in a competitive disadvantage with carbonatogenic bacteria selectively activated by the treatment. This is important, as it implies that the bacterial conservation treatment not only helps to protect and consolidate the treated substrate, but also reduces potential microbial biodeterioration processes. 


\section{Conclusions and Future Prospects}

The sculptural and built stone heritage suffers several weathering processes that endangers its survival. To halt or mitigate the effects of such weathering phenomena, different protection and consolidation treatments have been developed and applied in the past, most of them with limited effectiveness. In recent years, the biomineralization of calcium carbonates by carbonatogenic bacteria has been proposed as a novel, highly effective, environmentally friendly method for the protection and consolidation of decayed stone. Three basic bacterial biomineralization-based conservation methods have been proposed: (i) Inoculation of a single bacterial strain (either exogenous or collected from the stone substrate to be treated) culture; (ii) Activation of the indigenous carbonatogenic bacteria present in the stone via the application of a sterile nutritional solution; and (iii) Self-inoculation of the stone with the indigenous carbonatogenic bacterial community extracted from the decayed stone, cultured in the laboratory and re-applied to the stone. Each of these methods has its advantages and shortcomings. Nonetheless, the high effectiveness and easiness of application of the second method (application of a sterile nutritional solution) offers a most versatile and efficient bacterial conservation method for stone protection and consolidation. However, in specific cases where extreme deterioration is observed, as could be the case of heavily damaged stone subjected to salt weathering, the third method, i.e., self-inoculation, seems to be the most effective conservation approach. For the successful application of the last two methods, a prerequisite is the existence in the stone to be treated of a population of indigenous carbonatogenic bacteria. Remarkably, numerous studies have shown that in nearly all stone substrates and environments on the Earth surface, carbonatogenic bacteria are abundant. This explains why so far all in situ applications of the second and third bacterial conservation methods have been successful.

Future studies should further explore if the proposed bacterial conservation methods are equally effective in extreme environments, such as hot and humid tropical sites, desert areas, or very cold environments. Studies should also be performed to identify and quantify carbonatogenic bacteria in stones located in such different environments. Also, the effectiveness of the bacterial protection and consolidation treatments discussed here should be further tested for the case of non-carbonate stone (e.g., sandstones, granites) and man-made materials, such as lime-based mortars, gypsum plasters, ceramics, and earthen constructions. Finally, it would be enlightening to evaluate in detail what is the impact of the abovementioned bacterial conservation methods on the microbiota existing in the treated materials, and whether these treatments can help to reduce microbial biodeterioration.

Acknowledgement This work was carried out with the financial support of the European Regional Development Fund (ERDF) co-financed grant RTI2018-099565-B-I00 (MINECO Secretaría de Estado de Investigación, Desarrollo e Innovación, Spain), Proyecto de Excelencia RNM-3943, Research Groups RNM-179 and BIO-103 (Consejería de Economía, Innovación, Ciencia y Empleo, Junta de Andalucía), and the Unit of Research Excellence UCE- PP2016-05 of the University of Granada. 


\section{References}

Adolphe JP, Loubière JF, Paradas, J, Soleilhavoup F (1990) Procédé de traitement biologique d'une surface artificielle. European Patent 90400G97.0 (after French patent 8903517, 1989)

Baeuerlein E (2004) Biomineralization: progress in biology, molecular biology and application. John Wiley \& Sons, Weinheim

Barabesi C, Galizzi A, Mastromei G, Rossi M, Tamburini E, Perito B (2007) Bacillus subtilis gene cluster involved in calcium carbonate biomineralization. J Bacteriol 189:228-235

Bäuerlein E (2003) Biomineralization of unicellular organisms: an unusual membrane biochemistry for the production of inorganic nano- and microstructures. Angew Chem Int Ed 42:614-641

Bazylinski DA, Moskowitz BM (1997) Microbial biomineralization of magnetic iron minerals: microbiology, magnetism and environmental significance. Rev Mineral 35:217-223

Bazylinski DA, Schübbe S (2007) Controlled biomineralization by and applications of magnetotactic bacteria. Adv Appl Microbiol 62:21-62

Ben Omar N, Arias JM, González-Muñoz MT (1997) Extracellular bacterial mineralization within the context of geomicrobiology. Microbiologia 13:161-172

Ben Omar N, Entrena M, González-Muñoz MT, Arias JM, Huertas F (1994) Effects of pH and phosphate on the production of struvite by Myxococcus xanthus. Geomicrobiol J 12:81-90

Ben Omar N, Gonzalez-Muñoz MT, Peñalver JMA (1998) Struvite crystallization on Myxococcus cells. Chemosphere 36:475-481

Ben Omar N, Martínez-Cañamero M, González-Muñoz MT, Arias JM, Huertas F (1995) Myxococcus xanthus' killed cells as inducers of struvite crystallization. Its possible role in the biomineralization processes. Chemosphere 30:2387-2396

Boquet E, Boronat A, Ramos-Cormenzana A (1973) Production of calcite (calcium carbonate) crystals by soil bacteria is a general phenomenon. Nature 246:527-529

Braissant O, Cailleau G, Dupraz C, Verrecchia EP (2003) Bacterially induced mineralization of calcium carbonate in terrestrial environments: the role of exopolysaccharides and amino acids. J Sediment Res 73:485-490

Brennan ST, Lowenstein TK, Horita J (2004) Seawater chemistry and the advent of biocalcification. Geology 32:473-476

Buczynski C, Chafetz HS (1991) Habit of bacterially induced precipitates of calcium carbonate and the influence of medium viscosity on mineralogy. J Sediment Res 61:226-233

Cappitelli F, Toniolo L, Sansonetti A, Gulotta D, Ranalli G, Zanardini E, Sorlini C (2007) Advantages of using microbial technology over traditional chemical technology in removal of black crusts from stone surfaces of historical monuments. Appl Environ Microbiol 73:5671-5675. https://doi.org/10.1128/AEM.00394-07

Castanier S, Le Métayer-Levrel G, Orial G, Loubiere JF, Perthuisot JP (2000) Bacterial carbonatogenesis and applications to preservation and restoration of historic property. In: Ciferri O, Tiano P, Mastromei G (eds) Of microbes and art: the role of microbial communities in the degradation and protection of cultural heritage. Plenum, New York, pp 201-216

Chafetz H, Rush PF, Utech NM (1991) Microenvironmental controls on mineralogy and habit of $\mathrm{CaCO}_{3}$ precipitates: an example from an active travertine system. Sedimentology 38:107-126

Chekroun KB, Rodríguez-Navarro C, González-Muñoz MT, Arias JM, Cultrone G, RodríguezGallego M (2004) Precipitation and growth morphology of calcium carbonate induced by Myxococcus xanthus: implications for recognition of bacterial carbonates. J Sediment Res 74:868-876

Crispim CA, Gaylarde PM, Gaylarde CC (2003) Algal and cyanobacterial biofilms on calcareous historic buildings. Curr Microbiol 46:79-82

DaSilva EJ (2004) Art, biotechnology and the culture of peace. Electron J Biotechnol 7:130-166

Daskalakis MI, Magoulas A, Kotoulas G, Katsikis I, Bakolas A, Karageorgis AP, Mavridou A, Doulia D, Rigas F (2013) Pseudomonas, Pantoea and Cupriavidus isolates induce calcium carbonate precipitation for biorestoration of ornamental stone. J Appl Microbiol 115:409-423 
Daskalakis MI, Magoulas A, Kotoulas G, Katsikis I, Bakolas A, Karageorgis AP, Mavridou A, Doulia D, Rigas F (2014) Cupriavidus metallidurans biomineralization ability and its application as a bioconsolidation enhancer for ornamental marble stone. Appl Microbiol Biotechnol 98:6871-6883

Daskalakis MI, Rigas F, Bakolas A, Magoulas A, Kotoulas G, Katsikis I, Karageorgis AP, Mavridou A (2015) Vaterite bio-precipitation induced by Bacillus pumilus isolated from a solutional cave in Paiania, Athens, Greece. Int Biodeterior Biodegrad 99:73-84

De Belie N, Wang J, Bundur ZB, Paine K (2018) Bacteria-based concrete. In: Pacheco-Torgal F, Melchers RE, Shi X, Belie ND, Tittelboom KV, Sáez A (eds) Eco-efficient repair and rehabilitation of concrete infrastructures, Woodhead Publishing Series in Civil and Structural Engineering. Woodhead Publishing, Duxford, pp 531-567

De Muynck W, Cox K, De Belie N, Verstraete W (2008a) Bacterial carbonate precipitation as an alternative surface treatment for concrete. Constr Build Mater 22:875-885

De Muynck W, Debrouwer D, De Belie N, Verstraete W (2008b) Bacterial carbonate precipitation improves the durability of cementitious materials. Cem Concr Res 38:1005-1014

De Muynck W, De Belie N, Verstraete W (2010) Microbial carbonate precipitation in construction materials: a review. Ecol Eng 36:118-136

De Muynck W, Verbeken K, De Belie N, Verstraete W (2013) Influence of temperature on the effectiveness of a biogenic carbonate surface treatment for limestone conservation. Appl Microbiol Biotechnol 97:1335-1347

Dhami NK, Reddy MS, Mukherjee A (2014) Application of calcifying bacteria for remediation of stones and cultural heritages. Front Microbiol 5:209

Dick J, De Windt W, De Graef B, Saveyn H, Van der Meeren P, De Belie N, Verstraete W (2006) Bio-deposition of a calcium carbonate layer on degraded limestone by Bacillus species. Biodegradation 17:357-367

Doehne E, Price CA (2010) Stone conservation: an overview of current research. The Getty Conservation Institute, Los Angeles

Ehrlich HL (1998) Geomicrobiology: its significance for geology. Earth Sci Rev 45:45-60

Ettenauer J, Piñar G, Sterflinger K, Gonzalez-Muñoz MT, Jroundi F (2011) Molecular monitoring of the microbial dynamics occurring on historical limestone buildings during and after the in situ application of different bio-consolidation treatments. Sci Total Environ 409:5337-5352

Flatt RJ, Caruso F, Sanchez AMA, Scherer GW (2014) Chemo-mechanics of salt damage in stone. Nat Commun 5:4823

Folk RL (1993) SEM imaging of bacteria and nannobacteria in carbonate sediments and rocks. J Sediment Res 63:990-999

Fortin D (1997) Surface-mediated mineral development. Rev Mineral 35:162-180

Gonzalez-Muñoz MT, Arias JM, Montoya E, Rodriguez-Gallego M (1993) Struvite production by Myxococcus coralloides D. Chemosphere 26:1881-1887

González-Muñoz MT, Chekroun KB, Aboud AB, Arias JM, Rodriguez-Gallego M (2000) Bacterially induced $\mathrm{Mg}$-calcite formation: role of $\mathrm{Mg}^{2+}$ in development of crystal morphology. $\mathrm{J}$ Sediment Res 70:559-564

González-Muñoz MT, Fernández-Luque B, Martínez-Ruiz F, Ben Chekroun K, Arias JM, Rodríguez-Gallego M, Martínez-Cañamero M, de Linares C, Paytan A (2003) Precipitation of barite by Myxососcus xanthus: possible implications for the biogeochemical cycle of barium. Appl Environ Microbiol 69:5722-5725

Gonzalez-Muñoz MT, Rodriguez-Navarro C, Jimenez-Lopez C, Rodriguez-Gallego M (2008) Method and product for protecting and reinforcing construction and ornamental materials. Spanish patent WO 2008/009771 A1

González-Muñoz MT, Rodriguez-Navarro C, Martínez-Ruiz F, Arias JM, Merroun ML, RodriguezGallego M (2010) Bacterial biomineralization: new insights from Myxococcus-induced mineral precipitation. Geol Soc Lond Spec Publ 336:31-50

Hansen EF, Doehne E, Fidler JM, Larson JD, Martin BL, Matteini M, Rodriguez-Navarro C, Pardo EMS, Price CS, de Tagle A, Teutonico JM, Weiss N (2003) A review of selected inorganic 
consolidants and protective treatments for porous calcareous materials. Stud Conserv (sup 1) 49:13-25

Heidari Nonakaran S, Pazhouhandeh M, Keyvani A, Abdollahipour FZ, Shirzad A (2015) Isolation and identification of Pseudomonas azotoformans for induced calcite precipitation. World J Microbiol Biotechnol 31:1993-2001

Jimenez-Lopez C, Jroundi F, Pascolini C, Rodriguez-Navarro C, Piñar-Larrubia G, RodriguezGallego M, González-Muñoz MT (2008) Consolidation of quarry calcarenite by calcium carbonate precipitation induced by bacteria activated among the microbiota inhabiting the stone. Int Biodeterior Biodegradation 62:352-363

Jimenez-Lopez C, Rodriguez-Navarro C, Piñar G, Carrillo-Rosúa FJ, Rodriguez-Gallego M, Gonzalez-Muñoz MT (2007) Consolidation of degraded ornamental porous limestone stone by calcium carbonate precipitation induced by the microbiota inhabiting the stone. Chemosphere 68:1929-1936

Jroundi F, Fernández-Vivas A, Rodriguez-Navarro C, Bedmar EJ, González-Muñoz MT (2010) Bioconservation of deteriorated monumental calcarenite stone and identification of bacteria with carbonatogenic activity. Microb Ecol 60:39-54

Jroundi F, Gómez-Suaga P, Jimenez-Lopez C, González-Muñoz MT, Fernandez-Vivas MA (2012) Stone-isolated carbonatogenic bacteria as inoculants in bioconsolidation treatments for historical limestone. Sci Total Environ 425:89-98

Jroundi F, Gonzalez-Muñoz MT, Rodriguez-Navarro C, Martin-Peinado B, Martin-Peinado J (2013) Conservation of carbonate stone by means of bacterial carbonatogenesis: evaluation of in situ treatments. In: Koui M, Koutsoukos P, Zezza F (eds) Proceedings of the 8th international symposium on the conservation of monuments in the Mediterranean basin. Patras. Technical Chamber of Greece, Patras, pp 159-171

Jroundi F, Gonzalez-Muñoz MT, Sterflinger K, Piñar G (2015) Molecular tools for monitoring the ecological sustainability of a stone bio-consolidation treatment at the Royal Chapel, Granada. PLoS One 10:e132465

Jroundi F, Schiro M, Ruiz-Agudo E, Elert K, Martín-Sánchez I, González-Muñoz MT, RodriguezNavarro C (2017) Protection and consolidation of stone heritage by self-inoculation with indigenous carbonatogenic bacterial communities. Nat Commun 8:279

Knoll AH (2003) Biomineralization and evolutionary history. Rev Mineral Geochem 54:329-356

Lazzarini L, Laurenzi Tabasso M (2010) Il Restauro della Pietra. Utet Scienze Techniche, Torino

Le Métayer-Levrel G, Castanier S, Orial G, Loubière J-F, Perthuisot J-P (1999) Applications of bacterial carbonatogenesis to the protection and regeneration of limestones in buildings and historic patrimony. Sediment Geol 126:25-34

Lowenstan HA, Weiner S (1989) On biomineralization. Oxford University Press, New York

Mann S (1995) Biomineralization and biomimetic materials chemistry. J Mater Chem 5:935-946

Mastromei G, Marvasi M, Perito B (2008) Studies on bacterial carbonate precipitation for stone conservation. In: Proc. of 1st BioGeoCivil engineering conference, Delft, Netherlands. Delft University of Technology, Delft, pp 104-106

May E (2005) Biobrush research monograph: novel approaches to conserve our European heritage. EVK4-CT-2001-00055

Mihajlovski A, Gabarre A, Seyer D, Bousta F, Di Martino P (2017) Bacterial diversity on rock surface of the ruined part of a French historic monument: the Chaalis abbey. Int Biodeterior Biodegradation 120:161-169

Negi A, Sarethy IP (2019) Microbial biodeterioration of cultural heritage: events, colonization, and analyses. Microb Ecol 78:1014-1029

Okwadha GDO, Li J (2010) Optimum conditions for microbial carbonate precipitation. Chemosphere 81:1143-1148

Orial G (2000) La biomineralisation appliquée à la conservation du patrimoine: bilan de dix ans d'experimentation. In: XXI Siglo SA (ed) Restaurar la memoria, Actas del Congreso, Internacional AR\&PA 2000, Fundación del Patrimonio Histórico de Castilla y León. Arganda del Rey, Madrid 
Orial G, Castanier S, Metayer GL, Loubière JF (1993) The biomineralization: a new process to protect calcareous stone; applied to historic monuments. In: Ktoishi H, Arai T, Yamano K (eds) Proceedings of the 2nd international conference on biodeterioration of cultural property. International Communications Specialists, Tokyo, Japan, pp 98-116

Paerl HW, Steppe TF, Reid RP (2001) Bacterially mediated precipitation in marine stromatolites. Environ Microbiol 3:123-130

Perito B, Biagiotti L, Daly S, Galizzi A, Tiano R, Mastromei G (1999) Bacterial genes involved in calcite crystal precipitation. In: Ciferri O, Tiano P, Mastromei G (eds) Of microbes and art: the role of microbial communities in the degradation and protection of cultural heritage, international conference on microbiology and conservation. Kluwer, New York, pp 219-230

Perito B, Mastromei G (2011) Molecular basis of bacterial calcium carbonate precipitation. Prog Mol Subcell Biol 52:113-139

Price C, Ross K, White G (1988) A further appraisal of the "lime technique" for limestone consolidation, using a radioactive tracer. Stud Conserv 33:178-186

Rivadeneyra MA, Delgado R, del Moral A, Ferrer MR, Ramos-Cormenzana A (1994) Precipatation of calcium carbonate by Vibrio spp. from an inland saltern. FEMS Microbiol Ecol 13:197-204

Rodriguez-Navarro C, Doehne E (1999) Salt weathering: influence of evaporation rate, supersaturation and crystallization pattern. Earth Surf Process Landf 24:191-209

Rodriguez-Navarro C, González-Muñoz MT, Jimenez-Lopez C, Rodriguez-Gallego M (2011) Bioprotection. In: Reitner J, Thiel V (eds) Encyclopedia of geobiology. Springer, Netherlands, Dordrecht, pp 185-189

Rodriguez-Navarro C, Jimenez-Lopez C, Rodriguez-Navarro A, Gonzalez-Muñoz MT, RodriguezGallego M (2007) Bacterially mediated mineralization of vaterite. Geochim Cosmochim Acta 71:1197-1213

Rodriguez-Navarro C, Jroundi F, Gonzalez-Muñoz MT (2015) Stone consolidation by bacterial carbonatogenesis: evaluation of in situ applications. Restor Build Monum 21:9-20

Rodriguez-Navarro C, Jroundi F, Schiro M, Ruiz-Agudo E, González-Muñoz MT (2012) Influence of substrate mineralogy on bacterial mineralization of calcium carbonate: implications for stone conservation. Appl Environ Microbiol 78:4017-4029

Rodriguez-Navarro C, Rodriguez-Gallego M, Chekroun KB, Gonzalez-Muñoz MT (2003) Conservation of ornamental stone by Myxососcus xanthus-induced carbonate biomineralization. Appl Environ Microbiol 69:2182-2193

Rodriguez-Navarro C, Ruiz-Agudo E (2018) Nanolimes: from synthesis to application. Pure Appl Chem 90:523-550

Rodriguez-Navarro C, Sebastian E (1996) Role of particulate matter from vehicle exhaust on porous building stones (limestone) sulfation. Sci Total Environ 187:79-91

Rodriguez-Navarro C, Suzuki A, Ruiz-Agudo E (2013) Alcohol dispersions of calcium hydroxide nanoparticles for stone conservation. Langmuir 29:11457-11470

Saiz-Jimenez C (1997) Biodeterioration vs biodegradation: the role of microorganisms in the removal of pollutants deposited on historic buildings. Int Biodeterior Biodegradation 40:225-232

Sassoni E, Naidu S, Scherer GW (2011) The use of hydroxyapatite as a new inorganic consolidant for damaged carbonate stones. J Cult Herit 12:346-355

Schiro M, Ruiz-Agudo E, Rodriguez-Navarro C (2012) Damage mechanisms of porous materials due to in-pore salt crystallization. Phys Rev Lett 109:265503

Sebastián E, Rodríguez-Navarro C (1995) Alteración y conservación de materiales pétreos ornamentales: antecedentes y estado actual de conocimientos. Ingeniería Civil 96:167-178

Seifan M, Berenjian A (2019) Microbially induced calcium carbonate precipitation: a widespread phenomenon in the biological world. Appl Microbiol Biotechnol 103:4693-4708

Sharma O (2013) Characterization of novel carbonic anhydrase from halophilic bacterial isolates and it's role in microbially induced calcium carbonate precipitation (Ms Thesis). Thapar University, India 
Strzelczyk AB (1981) Stone. In: Rose AH (ed) Microbial biodeterioration. Academic Press, London, pp 61-80

Tiano P (1995) Stone reinforcement by calcite crystal precipitation induced by organic matrix macromolecules. Stud Conserv 40:171-176

Tiano P, Biagiotti L, Mastromei G (1999) Bacterial bio-mediated calcite precipitation for monumental stones conservation: methods of evaluation. J Microbiol Methods 36:139-145

Urosevic M, Yebra-Rodríguez A, Sebastián-Pardo E, Cardell C (2012) Black soiling of an architectural limestone during two-year term exposure to urban air in the city of Granada (S Spain). Sci Total Environ 414:564-575

Vasconcelos C, McKenzie JA, Bernasconi S, Grujic D, Tiens AJ (1995) Microbial mediation as a possible mechanism for natural dolomite formation at low temperatures. Nature 377:220-222

Warscheid T, Braams J (2000) Biodeterioration of stone: a review. Int Biodeterior Biodegrad 46:343-368

Webster A, May E (2006) Bioremediation of weathered-building stone surfaces. Trends Biotechnol 24:255-260

Wheeler G (2005) Alkoxysilanes and the consolidation of stone. The Getty Conservation Institute, Los Angeles

Zamarreño DV, Inkpen R, May E (2009) Carbonate crystals precipitated by freshwater bacteria and their use as a limestone consolidant. Appl Environ Microbiol 75:5981-5990

Zavarzin GA (2002) Microbial geochemical calcium cycle. Microbiology 71:1-17

Open Access This chapter is licensed under the terms of the Creative Commons Attribution 4.0 International License (http://creativecommons.org/licenses/by/4.0/), which permits use, sharing, adaptation, distribution and reproduction in any medium or format, as long as you give appropriate credit to the original author(s) and the source, provide a link to the Creative Commons license and indicate if changes were made.

The images or other third party material in this chapter are included in the chapter's Creative Commons license, unless indicated otherwise in a credit line to the material. If material is not included in the chapter's Creative Commons license and your intended use is not permitted by statutory regulation or exceeds the permitted use, you will need to obtain permission directly from the copyright holder. 